\title{
Henry Charlton Bastian (1837-1915): Neglected Neurologist and Scientist
}

\author{
J.M.S. Pearce \\ Emeritus Consultant Neurologist, Department of Neurology, Hull Royal Infirmary, Hull, UK
}

\section{Key Words}

Henry Charlton Bastian • Bastian's law • Aphasia •

Kinaesthetic cortex $\cdot$ Ascending spinocerebellar tract •

Abiogenesis

\begin{abstract}
Henry Charlton Bastian was born in Truro, Cornwall. He graduated in 1861 at the University College, London, where he worked most of his life. He was one of the first neurologists appointed to the National Hospital, Queen Square. There, he conducted original investigations and pursued wide interests both in medical and biological sciences. He was elected a Fellow of the Royal Society in 1868. In addition to his reputation as a neurological diagnostician and intellectual, he became an advocate of the vexed doctrine of abiogenesis.

Copyright $\odot 2010$ S. Karger AG, Base
\end{abstract}

In the first half of the 19th century, despite a few notable contributions of Charles Bell, Marshall Hall, and Robert Bentley Todd, neurology in Britain had become relatively stagnant [1]. The foundation of the 'Hospital for the Paralysed and Epileptic' (later named: National Hospital for Nervous Diseases) in 1859, was prompted by the remarkable labours of two sisters, Louisa and Johanna
Chandler who, greatly troubled by the inadequacies of care available to their grandfather, stricken with paralysis, raised funds and mayoral support for a new hospital which aimed to provide skilled and humane treatment for the neurologically sick. No. 24, Queen Square was found suitable and permitted an outdoor clinic, as well as accommodation for 10 in-patients. The founding physicians were Jabez Spence Ramskill (1824-1897) and Charles Edouard Brown-Séquard (1817-1894). In 1862, John Hughlings Jackson (1837-1911) was appointed. This paper concentrates on Bastian, who joined their ranks in 1868. In a short time, the hospital took on its staff the gifted David Ferrier, William Allen Sturge, William Gowers, Victor Horsley, and a succession of notable physicians and surgeons.

\section{Henry Charlton Bastian (1837-1915) (fig. 1)}

Bastian was the third son of James Bastian, a merchant, and Charlotte Eliza Bullmore. Born in Truro, after attending school in Falmouth, he entered University College, London, in 1856, and graduated BA, MB in 1863, and served as Assistant Curator in University College Museum. He passed the MRCP (1865) and MD (1866), and was quickly elected FRCP in 1870 . He became a lecturer in pathology at St. Mary's Hospital, and in 1867 was

\section{KARGER}

Fax +4161306 1234 E-Mail karger@karger.ch www.karger.com (c) 2010 S. Karger AG, Basel

0014-3022/10/0632-0073\$26.00/0

Accessible online at:

www.karger.com/ene
J.M.S. Pearce

304 Beverley Road

Anlaby, East Yorks HU10 7BG (UK) 


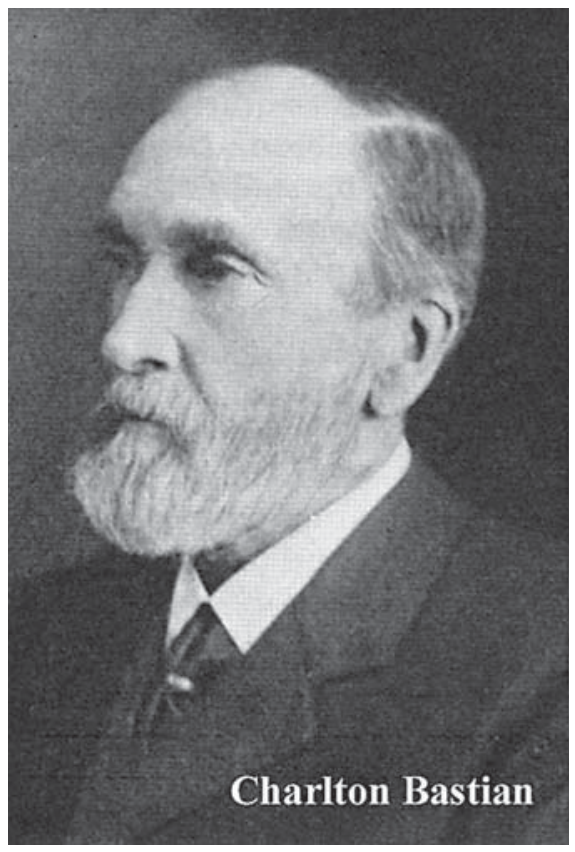

Fig. 1. H.C. Bastian.

appointed Professor of Pathology and Assistant Physician at UCH. His rapid ascent tells of his unusual ability. He successively became Professor of Clinical Medicine, UCH Medical School, and Assistant Physician to the $\mathrm{Na}$ tional Hospital for the Paralysed and Epileptic (1868), then full Physician (1887). He was one of a select band including Gowers and Hughlings Jackson, who pioneered scientific neurology.

For over 40 years he served at the National Hospital (1868 until retirement in 1912). At the same time he pursued his interest in bacteriology experiments, which he conducted behind a screen in his consulting room at $8 \mathrm{~A}$ Manchester Square, London.

In 1866 he married Julia Augusta Orme; they were to have three sons and one daughter [2]. Ironically, despite a brilliant and varied career [3], his life ended in poverty [4]. After he retired, Bastian's clinical practice declined. Jellinek recounts $[3,4]$ how financially straitened, he was forced to move to a small mortgaged house in the Chilterns. He had received a pension from neither his London hospitals nor university appointments. Eventually, his colleague Sir James Crichton-Browne, with support from the influential geologist Sir James Geikie, a former President of the Royal Society, Sir Thomas Barlow, President of the Royal College of Physicians and Sir William Ramsay, a distinguished chemist, wrote to Asquith, who was
Prime Minister. Bastian eventually received a Civil List pension in 1914.

It is condign that his legacy endures. As one of the first consultants at Queen Square, his influence on neurology was considerable. His studies encompassed not only natural history and theories of the origins of life, but also clinical aspects of hysteria, new concepts of the aphasias, and original anatomical observations. For almost 30 years he advanced his credited views of the 'kinaesthetic cortex'. Bastian's ideas on abiogenesis were at the time the object of derision, yet in the light of discoveries of the last 60 years, the principles he espoused have prompted more recent scientific enquiries.

\section{Bastian's Neurology}

Bastian's clinical studies yielded several texts. Hitzig and Ferrier had debated the notion of muscle sense and proprioception, but it was Bastian who from the late 1860s claimed that muscle sense was necessary for the brain to coordinate movement $[5,6]$.

He described small vessel emboli as a cause of delirium and stupor in febrile illnesses [7], a novel concept which subsequently was verified in certain cases.

A monograph in 1875 considered at length the manifestations of paralysis in brain diseases, discussing hemiplegia and its varied localisations and aetiologies that included epilepsy, emotional states and hysteria [8].

Probably his most important book was The Brain as Organ of the Mind (Paris edition 1888, shown in fig. 2) which discussed the comparative anatomy and physiology of the nervous system [9].

In his monograph, Various Forms of Hysterical or Functional Paralysis [10], he distinguished hysteria proper from other functional disorders. Thus, the hemianaesthesia of internal capsular lesions could resemble hysterical hemianaesthesia. Among nine categories of acute spinal paralysis, Bastian described in his book Hysterical Paraplegia in a way that reveals the imperfect knowledge of organic nervous disease in Bastian's day. It constitutes, he says, a 'special class' of functional paralysis, difficult accurately to differentiate, and then only by a dangerous process of exclusion of organic disease. While hysterical paralysis is functional, not all functional paralyses, he says, are hysterical.

The next item is (d) paraplegia dependent on idea. How Bastian differentiates this from hysterical paraplegia is not clear [11], for he says that it is characterized by 'the absence of any positive indications of structural de- 


\section{LE GERVEAU \\ COYNR}

\section{ORGANB DE LA PENSÉE \\ CHEZ LES ANIMAOX BT GHE LHONAE}

\section{LIVRB IV

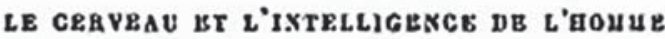

\author{
CliAPITRE XIX \\ DEVELOTPEAEST DU CEnTEAU zUHATK \\ PEXOAXY LA VIE UTERISE
}

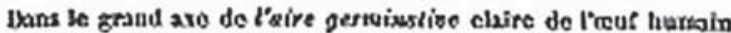
uconde, opparait une ligso opaque de tiare Jeune, connus sotas lo now do corde darsale.

Att-dessus do oelle-ci, es tout is long de son étcesdoc, on troure un sillav pritsitif, qui est blentost lisajts de chaque coté par une lame erandissante do tissu cabryonnaliv. Ces lames so rapprochent l'une \$s lyutro, ot fintsoent par so niunir als-lesess du sillen prisuitif sus.menticeni, do manketro a former un tube distinct, ferró a chanue bout.

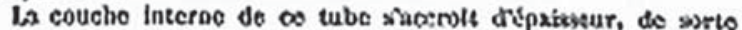
qu'll devieat gradooikement plas ćtrolt. Ellte ws differeexio bientot arsoj en dear toosa distinets. Ia plus Interne des souclies, e'cet-á.

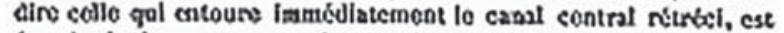
formele de tiau neereux embrjonasiro; et ciest detho que $x$ ditroloppo l'axe cénioro-epinal.

Lo diatndere de set axe nerveax rodimentaire, et croux. neest point usiformo dans touto zon étendtos. Meme avant que les lames se

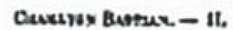

Fig. 2. Le cerveau comme organe de la pensée (The Brain as Organ of the Mind), 1880. (Paris edition, Alcan 1888).

fect in the spinal cord'; that 'it occurs in persons of delicate or neurotic constitution' and is probably due to 'imagination continuously excited in one direction and with a tendency to pervert spinal cord activity in that region' [12].

He dismissed Gall's phrenology, and favoured cortical localisation advocated by Ferrier and others [13], though interestingly, he denied the identity of a discrete motor cortex.

Henry Charlton Bastian (1837-1915)

\section{Speech Disorders}

Whilst studying kinaesthesia (see below), he also turned his attention to studies on aphasia, which he pursued for over 30 years. He described [14] two examples of motor aphasia with agraphia, and dyslexia. Thus, he broadened the range of aphasia from Broca's aphemia and Trousseau's amnesic aphasia to include agraphia, receptive aphasia, and alexia, pointing out the visual and auditory components of language. He confirmed the opinions of his friend Herbert Spencer that all thought was dependent on words:

'We think in words in fact, and these words are received as sound impressions in the auditory receptive centres of the cerebral hemispheres.'

Head credited him with descriptions of sensory aphasia from posteriorly sited lesions some 5 years before Wernicke (1874), who had failed to mention Bastian's contribution [15]. However, neither provided pathological evidence, and Bastian believed that sensory aphasia had no independent existence [16]. He said that aphasia related to damage to one of four centres for speech: the posteriorly placed (temporal) auditory word centre, the parietal visual word centre, the anteriorly placed frontal 'glosso-kinaesthetic' centre, and the 'cheiro-kinaesthetic' centre for hand movement. But when he published [17] post-mortem findings in a man who had a devastating left-hemisphere stroke with total aphasia 18 years previously but who had later learnt to read again, the huge lesion was not compatible with Bastian's speech schema. It was, he said, 'a puzzling riddle'. His aphasia studies were published in the Lumleian Lectures of 1897 [18] and in a treatise of 1898 , which were widely respected [15].

\section{Kinaesthesia and the Motor Cortex}

Bastian's studies allowed him to assert that muscle sense was necessary for the brain to coordinate movement $[5,19]$. He realized that this was an unconscious sensation:

'... the brain is assisted in the execution of movements by guiding impressions of some kind which, whilst they differ from the impressions of the ordinary cutaneous and deep sensibility, may differ still further from these owing to the fact of their not being revealed in consciousness' [14].

In order to dispute cortical motor centres, he republished his 1892 paper in Brain 'On the neural processes 
underlying attention and volition' [20]; 'it is all kinaesthesia' he said. Bastian initiated the word kinaesthetic in 1880 , but the exact source of voluntary motion was unclear. Like others of his generation he considered the cerebellum, but following Bright, he later attributed movement to a cortical location. Like Spencer, he believed muscle sense must be received before a motor act was possible, and muscle sense acted on the motor cortex that was the site of movement. Thus, the motor cortex was a kinaesthetic cortex for stored images, which in turn determined patterns of movement. Hugo Liepmann and Hermann Munk supported this concept. Victor Horsley too, referred to:

'sensory functions were disordered which are directly connected with the accurate evolution of a movement, and constitute his [Munk's] "memories of movement" ' [21].

Bastian's description of the frontal speech centres as 'kinaesthetic' rather than motor accords with his earlier denial of any purely motor centres in the cerebral cortex. At the second meeting of the London Neurological Society in 1888, in a heated discussion, he said: '[there was] ... no longer the faintest need to postulate the existence of cortical motor centres'. Later, Sherrington replaced the term kinaesthetic sense with proprioception, and regarded the cerebellum as 'the head-ganglion of the proprioceptive system' [22].

\section{Spinal Cord Lesions}

An able anatomist, Bastian's first major publication in Neurology was about the identification of a degenerated tract in the spinal cord, which was later named Gowers' tract. In 1867, Bastian studied the spinal cord of a young man who had a partially transected cervical cord enlargement after a fall 6 months before his death. He applied the methods of Augustus Waller and Ludwig Turck on nerve and tract degeneration (made possible by Benedikt Stilling's (1810-1879) invention of the microtome in 1842) to demonstrate the ascending spinocerebellar tract. Bastian stained the cord with chromic acid, which left degenerated tracts in the ventral columns. MacNalty and Horsley, 42 years later, thought that Bastian had described the spinocerebellar tract, known after 1880 - despite Gowers' known distaste for eponyms - as Gowers' tract.

Bastian observed in 1890 that in 4 patients with cervical cord transections the tendon reflexes below the lesion were absent, and this became the basis for 'Bastian's law'
[23]. He was largely responsible for establishing transverse myelitis and separating it from non-inflammatory transverse myelopathies. There was a popular concept at the time for diagnosing all cord lesions of unknown cause as inflammatory myelitis, which Bastian repeatedly rejected [24]. He described several cases of 'acute myelitis' resulting in 'softening of the spinal cord'. He presented his pathologic findings [25] and divided them into those due to 'blood changes and toxins, often associated with feeble cardiac action, which may well act as causes of thrombosis in vessels of the spinal cord', and those due to acute inflammation. The 'inflammatory' cases he thought were caused by an infectious or allergic mechanism. Later, William Spiller was to confirm the concept of vascular myelopathy in 1909 when he demonstrated thrombosis in the anterior cervical spinal artery of John W., a hospital employee who developed a fatal tetraplegia, probably related to syphilis, but precipitated by lifting four $100-1 \mathrm{~b}$ ice blocks [26].

We can see that he was a physician with wide interests, and with diligent curiosity, he explored the pathogenesis of diverse neurological illnesses. Further, his clinical abilities as a diagnostician were widely acknowledged.

\section{Natural History}

Among his early publications was a complete flora of Falmouth and a collection of the ferns of Great Britain. Bastian was an authority on nematode worms and named 100 new species in his monograph The Anguillulidae, read to the Royal Society on 1st December $1864 .{ }^{1}$ He was elected FRS for this work in 1868, at the age of 31, but had to abandon this interest when he supposedly developed an allergy to the worms.

Throughout his career, he displayed qualities of unusual philosophical conjecture, which conduced to his unusually varied fields of enquiry. He carried out several experiments that led him to believe in 'Aristotelian abiogenesis', or spontaneous generation, according to which formed living organisms sometimes arise from non-living matter. Bastian became notorious for these controversial views [27] in which he was opposed by no less than T.H. Huxley, Pasteur and Tyndall. He consequently suffered much opprobrium. But many scientists, such as

\footnotetext{
1 J.D. Hooker in a letter to Charles Darwin, the very next day, described it as 'a capital paper on nematoid worms advocating the separation of the non-parasitic from the parasitic'.
} 
Huxley and Haldane, in parallel vein, continued to postulate a 'primordial archebiosis', in which the living organisms observed in the world had originally arisen in stages from non-living matter. Darwin in 1871 suggested that life might have begun in:

'a warm little pond, with all sorts of ammonia and phosphoric salts, lights, heat, electricity, etc. present, so that a protein compound was chemically formed ready to undergo still more complex changes ....

Darwin read Bastian's The Beginnings of Life, and wrote about it to Wallace (August 28th, 1872):

'His [Bastian's] general argument in favour of Archebiosis is wonderfully strong, though I cannot think much of some few of his arguments. The result is that I am bewildered and astonished by his statements, but am not convinced, though, on the whole, it seems to me probable that Archebiosis is true. I am not convinced, partly I think owing to the deductive cast of much of his reasoning.'

Bastian's opinions about abiogenesis, though much criticised, allow us a glimpse of the originality which was expressed in his more orthodox medical works. Even in the year of his death he published in Nature [1915;95:537538]:

'I desire to direct the attention of readers of Nature to the influence of tyrosine in promoting the growth and multiplication of any organisms that may be found in tubes five to ten months after they have been hermetically sealed and sterilised, ....

He still adhered to his convictions about abiogenesis [28]. He published four further monographs: Studies in Heterogenesis (1901-1904), The Nature and Origin of Living Matter (1905), The Evolution of Life (1907), and Remarks on Further Experiments Concerning the Origin of Life (1912) (fig. 3). But eventually, because of his heterodox views, he found it difficult to get his work accepted by reputable journals ${ }^{2}$. More recent variant hypotheses of 'Panspermia's , and Sir Francis Crick's postulated 'Directed Panspermia' [29] show Bastian's ideas, if not his methods, were far from obsolete. The well-known Miller-Urey experiment in 1953 demonstrated how simple amino acids could have arisen abiotically. Thus, the issues of abiogenesis and the primordium to this day remain unresolved $^{4,5}$

He died aged 75, at his humble home, Fairfield, Chesham Bois, Buckinghamshire, on 17 November 1915. He was cremated and his ashes buried, probably at Kensal Green, London.

Perhaps overshadowed by Jackson and BrownSéquard, Bastian ranks highly as an original thinker and a stalwart of early British neurology.

\section{Proc Roy Soc Med \\ Patbological פection.}

November 19, 1912 .

Dr. R. T. Hewletr, President of the Section, in the Chair.

\section{Remarks on Further Experiments concerning the Origin of Life.}

By H. Charlton Bastian, M.D., F.R.S.

Mr work, entitled "The Origin of Life," was based in the main on 196 experiments with hermetically sealed tubes whose contents had been exposed to high temperatures. Since the date of its publication in the spring of 1911 I have performed a much larger series of experiments - as many as 280 - and consequently should be in a position entitling me (1) to pass some judgment on the value of my previous results; (2) to deal more or less authoritatively with the doubts expressed by others as to the validity of my conclusions; and (3) to offer some useful advice to those who may wish successfully to repeat my experiments.

\section{(I) The Nature of the Problem, and the Extent to which} it has been solved.

It has long been widely believed in the world of science that the occurrence of "spontaneous generation" is a myth. This view gathered strength thirty to forty years ago, seeing that the experiments of Pasteur, and later those of Tyndall, induced them to urge it with much insistence; and because, moreover, it has seemed to be in accord with the practice found needful in bacteriological inquiries of growing importance. In all their experiments Pasteur and Tyndall, $\mathrm{D}-23$

Fig. 3. Remarks on further experiments concerning the origins of life.

2 In The Origin of Life, Bastian tells of using two solutions. One consisted of 2 or 3 drops of dilute sodium silicate with 8 drops of liquor fern pernitratis to $1 \mathrm{oz}$ of distilled water. The other was composed of the same amount of the silicate with 6 drops of dilute phosphoric acid and 6 grains of ammonium phosphate. He filled sterilised tubes, sealed them hermetically, and heated them to 125 or $145^{\circ} \mathrm{C}$, 'although 60 or 70 degrees would have killed any bacteria remaining in them'. Next he exposed them to sunlight in a south window for from 2 to 4 months. When the tubes were opened Dr. Bastian found organisms in them which differed in no way from real bacteria. They grew and multiplied. He contended that he had proved the possibility of spontaneous generation of life.

Postulates microbial life is present in space or on comets or asteroids, and it can be delivered to planets and initiate life there. Panspermia was supported by Lord Kelvin, von Helmholtz, J.B.S. Haldane, and later by Fred Hoyle and Chandra Wickramasinghe.

4 Using water, methane, ammonia and hydrogen (materials believed to represent the major components of the early Earth's atmosphere) they showed in vitro that $10-15 \%$ of the carbon within the system could become organic compounds. Two percent of the carbon had formed amino acids, including 13 of the 22 used to make proteins in living cells.

5 Detailed review and references of the complex issues in: http://www. panspermia.org/intro.htm. 


\section{Appendix}

Works of Bastian recorded at The Royal Society.

The Royal Society - Citation:

Author of a memoir On the Anatomy and Physiology of the Nematoids, with Observations on Their Zoological Position \& c (Phil Trans, 1866);

Monograph on the Anguillulidae or Free Nematoids, with Descriptions of 100 New Species (Trans Linn Soc, 1865, vol 25);

A memoir On the Structure and Nature of the Dracunculus, or Guinea-Worm (Trans of Linnaean Soc, vol 24);
On the Specific Gravity of Different Parts of the Human Brain (Journal of Mental Sciences, January 1866, and translated in Archiv der Heilkunde, June 1866).

Archived Papers at The Royal Society:

On the Heterogenetic Origin of Certain Ciliated Infusoria from the Eggs of a Rotifier, 1905, by Henry Charlton Bastian.

Researches illustrative of the Physico-Chemical Theory of Fermentation. Part I, 1876, by Henry Charlton Bastian.

\section{References}

1 Critchley M: The beginnings of the National Hospital, Queen Square (1859-1860). Br Med J 1960;1:1829-1837.

2 Rang M: The Life and Work of Henry Charlton Bastian, 1954.

3 Jellinek EH: Dr. H.C. Bastian, scientific Jekyll and Hyde. Lancet 2000;356:2180-2183.

-4 Jellinek EH: Before the welfare state: Bastian's Civil List pension. J R Coll Physicians Edinb 2005;35:365-366.

5 Bastian HC: On the muscular sense and the physiology of thinking. Br Med J 1869;1:437463.

6 Bastian HC: The muscle sense: its nature and cortical localisation. Brain 1897;10:1-137.

7 Bastian HC: Emboli of small vessels of the brain by white globules. Br Med J 1869, pp 421-422.

8 Bastian HC: On Paralysis from Brain Diseases. London. Macmillan, 1875.

9 Bastian HC: The Brain as Organ of the Mind. London, Kegan Paul, 1880.

10 Bastian HC: Various Forms of Hysterical or Functional Paralysis. London, H.K. Lewis, 1893.

11 Walshe FMR: Diagnosis of hysteria. Br Med J 1965;2:1451-1454.

12 Bastian HC: Paralyses: Cerebral, Bulbar and Spinal. London, H.K. Lewis, 1886.
13 Pearce JMS: Sir David Ferrier MD, FRS. J Neurol Neurosurg Psychiatry 2003;74:787.

14 Bastian HC: On various forms of loss of speech. Br For Med Chi Rev 1869;43:209236.

15 Head H: Aphasia and Kindred Disorders of Speech, vol 1 \& 2. London, Cambridge University Press, 1926.

16 Bastian HC: A Treatise on Aphasia and Other Speech Defects. London, H.K. Lewis, 1898.

17 Bastian HC: On a case of amnesia and other speech defects of eighteen years' duration, with autopsy. Med Chir Sci Trans 1897;80: 61-86.3.

18 Bastian HC: The Lumleian Lectures on some problems in connexion with aphasia and other speech defects. Lancet 1897;149:10051017.

19 Bastian HC: The muscle sense: its nature and cortical localisation. Brain 1897;10:1-137.

20 Bastian HC: On the neural processes underlying attention and volition. Brain 1892;15: $1-34$.

21 Horsley V: The function of the so-called motor area of the brain. Br Med J 1909;2:125132 .
22 Sherrington CS: On the proprioceptive system, especially in its reflex aspect. Brain 1907;29:467-483.

23 Bastian HC: On the symptomatology of total transverse lesions of the spinal cord, with special reference to the condition of the various reflexes. Med Chir Trans 1890;73:151217.

24 Bastian HC: Thrombotic softening of the spinal cord: a case of so-called 'acute myelitis.' Lancet 1910;2:1531-1534.

25 Bastian HC: Special diseases of the spinal cord; in Quain R (ed): A Dictionary of Medicine: By Various Writers. London, Longmans, Green \& Co, 1882, pp 1479-1483.

26 Spiller WG: Thrombosis of the cervical anterior median spinal artery; syphilitic acute anterior poliomyelitis (abstract). J Nerv Ment Dis 1909;36:601-613.

-27 Bastian HC: Remarks on further experiments concerning the origin of life. Proc $\mathrm{R}$ Soc Med (Pathol) 1913;6:49-67.

28 Worboys M: Bastian (Henry) Charlton (1837-1915); Oxford Dictionary of National Biography. Oxford, Oxford University Press, 2004.

29 Orgel LE, Crick FHC: Anticipating an RNA world. Some past speculations on the origin of life: where are they today? FASEB 1993;7: 238-239. 